\title{
ANIMASI PEMBELAJARAN BIOLOGI UNTUK KELAS X SMA BERBASIS MULTIMEDIA
}

\author{
Purwanto, Yogi Meinarsih \\ Stb_banjarnegara@yahoo.com \\ Sekolah Tinggi Ilmu Manajemen Informatika Dan Komputer Tunas Bangsa Banjarnegara
}

\begin{abstract}
Abstrak
Metode pembelajaran Biologi di SMA ternyata masih belum bisa diterapkan secara optimal. Berbagai faktor terkait yang sering dihubungkan dengan rendahnya prestasi belajar Biologi tersebut antara lain mata pelajaran Biologi kurang disenangi, kurangnya minat para siswa dengan pembelajaran yang monoton dan belum memanfaatkan multimedia di dalam pembelajaran. Penggunaan teknologi multimedia dan animasi akan banyak membantu dalam menyelesaikan masalah ini. Tujuan penelitian ini adalah membuat program aplikasi Animasi Pembelajaran Biologi Semester 1 Untuk Kelas X di SMA Negeri 1 Sokaraja Berbasis Multimedia.Pengumpulan data dilakukan dengan metode observasi, wawancara, partisipasi, kuesioner, dan pengambilan sampel. Metode pengembangan sistem pada program aplikasi ini menggunakan metode Waterfall Model. Aplikasi ini dibangun menggunakan Adobe Flash CS3. Aplikasi ini diuji coba menggunakan metode Black Box Test.Penelitian ini telah menghasilkan program aplikasi Animasi Pembelajaran Biologi Semester 1 Untuk Kelas X di SMA Negeri 1 Sokaraja Berbasis Multimedia. Program aplikasi dinyatakan dapat memudahkan dan meningkatkan minat belajar siswa dengan prosentase $82,86 \%$, sedangkan prosentase keseluruhan program aplikasi adalah $82,86 \%$ untuk jawaban ya, dan $17,14 \%$ untuk jawaban tidak. Maka program aplikasi dapat membantu proses belajar mengajar materi Biologi di SMA.
\end{abstract}

Kata Kunci: Animasi pembelajaran, Multimedia, Adobe Flash CS3

\section{Pendahuluan}

Teknologi informasi saat ini berpengaruh besar terhadap kegiatan belajar mengajar. Dengan adanya perangkat pembelajaran berbasis multimedia, maka diharapkan bagi siswa agar lebih mudah memahami apa yang disampaikan oleh guru. Multimedia merupakan teknologi menggunakan komputer untuk menggabungkan grafik, animasi, video yang bersifat integrasi ke dalam suatu bentuk pengajaran dan pembelajaran yang interaktif. Multimedia ini berperan sebagai suatu alat komunikasi yang memberi kemudahan dalam proses pembelajaran yang berguna untuk membimbing dan memperluas proses pemikiran penggunanya.

Dalam dunia pendidikan, teknologi berperan penting dalam tumbuh kembangnya dunia pendidikan, karena teknologi pendidikan adalah kajian dan praktik untuk membantu proses belajar dan meningkatkan kinerja dengan membuat, menggunakan, dan mengelola proses sumber teknologi yang memadai.
Istilah teknologi pendidikan sering dihubungkan dengan teori belajar dan pembelajaran. Bila teori belajar dan pembelajaran mencakup proses dan sistem dalam belajar dan pembelajaran, maka teknologi pendidikan mencakup sistem lain yang dapat digunakan dalam proses mengembangkan kemampuan siswa.

SMA Negeri 1 Sokaraja yang terletak di jalan raya Sokaraja Timur ini adalah salah satu sekolah yang berusaha menjadi sekolah unggulan. Dengan adanya fasilitasfasilitas yang tersedia, salah satunya adalah ruang multimedia yang telah dimanfaatkan untuk proses pembelajaran interaktif yaitu pembelajaran ilmu Geografi, ilmu Kimia, dan ilmu Biologi. Mata pelajaran ilmu Biologi merupakan salah satu mata pelajaran kelas X, penyajian materi Biologi oleh guru yang menggunakan metode ceramah dapat menimbulkan rasa jenuh atau kebosanan para siswa pada saat guru menerangkan materi Biologi, sehingga menjadi tantangan bagi para guru bagaimana membuat para siswa tidak merasa bosan mendengarkan dan menyimak 
materi selama pelajaran berlangsung dan agar siswa dapat mengerti sekaligus memahami materi yang dipelajarinya.

Untuk mengatasi hal tersebut, penyampaian materinya adalah dengan menggunakan teknologi multimedia. Dimana penggunaan unsur teknologi multimedia dalam pembelajaran dengan animasi secara interaktif para siswa dapat langsung melihat, membaca, dan mendengar materi pembelajaran sehingga diharapkan dapat meningkatkan minat belajar siswa.

Mengingat begitu pentingnya media animasi dalam pembelajaran dan guna meningkatkan efektifitas kegiatan belajar mengajar di SMA Negeri 1 Sokaraja, maka peneliti merancang dan membuat media pembelajaran dengan judul "Animasi Pembelajaran Biologi Semester 1 Untuk Kelas X di SMA Negeri 1 Sokaraja Berbasis Multimedia" menggunakan Adobe Flash Profesional CS3.

\section{Metode Penelitian}

a. Pengumpulan Data

1) Wawancara

Adalah komunikasi dua arah untuk mendapatkan data dari responden (Jogiyanto, 2008:111).Dalam hal ini peneliti melakukan wawancara langsung dengan pihak Guru di SMA Negeri 1 Sokaraja.

2) Observasi

Yaitu merupakan teknik atau pendekatan untuk mendapatkan data primer dengan cara mengamati langsung obyek datanya (Jogiyanto, 2008:89).Pada proses ini peneliti melakukan pengamatan proses Kegiatan Belajar Mengajar yang sedang berlangsung pada kelas X di SMA Negeri 1 Sokaraja.

3) Metodologi pengembangan sistem

Waterfall Model: Model ini telah diperoleh dari proses engineering lainnya. Model ini menawarkan cara pembuatan perangkat lunak secara lebih nyata.(Ladjamuddin, 2006: 154)

\section{b. Pengujian Sistem}

Black Box Test: Pengujian fungsional atau pengujian kotak hitam (black-box test) merupakan pendekatan pengujian yang ujinya diturunkan dari spesifikasi program atau komponen. Sistem merupakan 'kotak hitam' yang perilakunya hanya dapat ditentukan dengan mempelajari input dan output yang berkaitan. Nama lain untuk cara ini adalah pengujian fungsional karena penguji hanya berkepentingan dengan fungsionalitas dan bukan implementasi perangkat lunak. (Sommerville, 2003: 87)

\section{Hasil dan pembahasan}

Aplikasi ini berisi tentang animasi pembelajaran Biologi materi kelas $\mathrm{X}$ semester 1 yang sesuai dengan kurikulum yang berlaku yaitu kurikulum berbasis kompetensi. Aplikasi ini dilengkapi dengan tampilan gambar, video, tampilan animasi untuk menambah daya tarik dan minat belajar siswa.

Berikut ini adalah tampilan program aplikasi animasi pembelajaran Biologi materi kelas X semester 1:

a. Tampilan menu Intro

Tampilan Intro ditampilkan pertama kali ketika dijalankan program aplikasi mengenai animasi pembelajaran Biologi materi kelas X semester 1. Pada halaman ini ditampilkan animasi teks dan animasi gambar burung serta animasi gambar matahari, tampilan intro berfungsi sebagai pengenalan program aplikasi mengenai animasi pembelajaran Biologi materi kelas $\mathrm{X}$ semester 1. Tampilan Intro dapat dilihat pada gambar berikut ini:

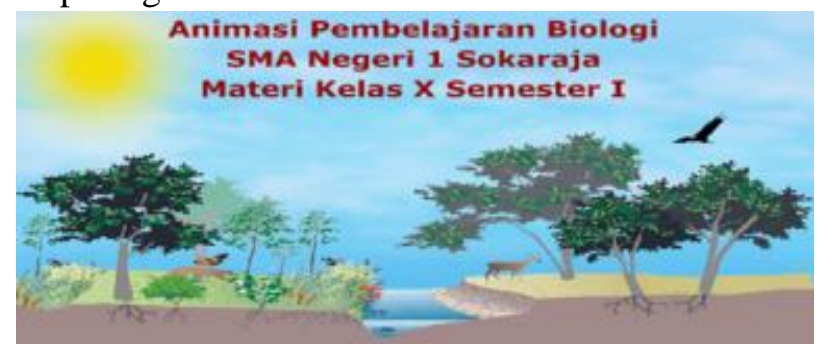

Gambar 1 Tampilan menu Intro

b. Tampilan halaman Menu Utama

Tampilan Menu Utama merupakan gerbang untuk melanjutkan ke halaman berikutnya dengan navigasi beberapa tombol yang telah di sediakan. Pada halaman Menu Utama ini ditampilkan animasi gambar mengenai pembelajaran Biologi dan tampilan jam digital. Tampilan Menu Utama dapat dilihat pada gambar berikut ini: 


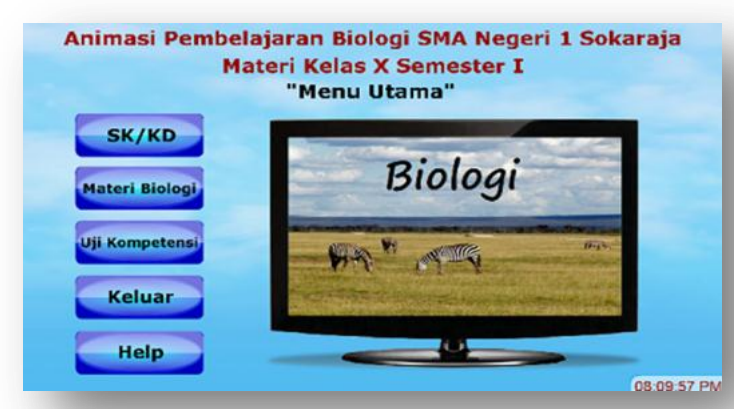

Gambar 2 Tampilan Menu Utama

\section{c. Tampilan Menu SKD}

Menu SK/KD membahas tentang materi SK/KD yang berlaku pada kurikulum berbasis kompetensi. Halaman ini dilengkapi dengan tombol Sebelumnya dan tombol Menu Utama yang berfungsi untuk kembali ke Menu Utama, adapun tomboltombol menu SK/KD Materi Biologi Kelas $\mathrm{X}$ Semester 1 yang berfungsi untuk menuju ke materi SK/KD tersebut. Tampilan menu SK/KD dapat dilihat pada gambar berikut ini:

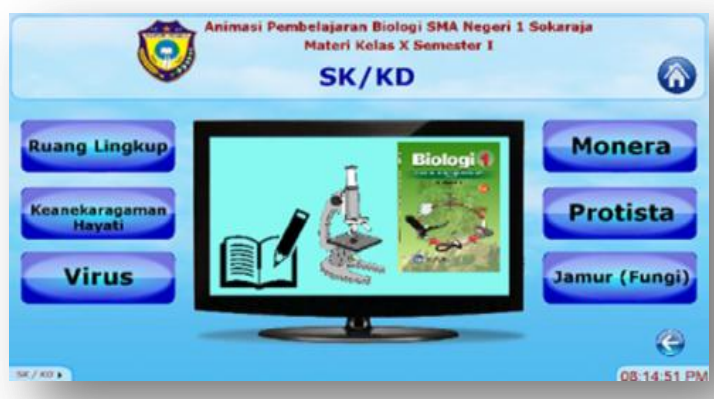

Gambar 3 Tampilan menu SK/KD

d. Tampilan halaman materi SK/KD Ruang Lingkup

Tampilan halaman materi SK/KD Ruang Lingkup merupakan gerbang untuk melanjutkan ke halaman materi SK/KD Ruang Lingkup berikutnya dengan navigasi beberapa tombol yang telah disediakan, diantaranya tombol Sebelumnya, tombol Berikutnya, dan tombol Menu Utama. Halaman ini berisi materi SK/KD Ruang Lingkup berupa teks. Berikut ini adalah tampilan halaman materi SK/KD Ruang Lingkup:

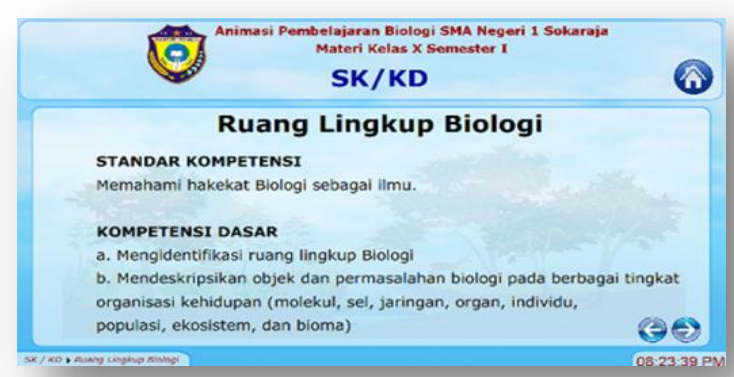

Gambar 5 Tampilan materi SK/KD Ruang Lingkup

e. Tampilan halaman menu Materi Biologi

Menu Materi Biologi merupakan gerbang untuk menuju ke materi Biologi kelas $\mathrm{X}$ semester 1 yang berlaku pada kurikulum berbasis kompetensi. Pada halaman ini terdapat enam tombol materi Biologi kelas X semester 1, yaitu : tombol materi Ruang Lingkup, tombol materi Keanekaragaman Hayati, tombol materi Virus, tombol materi Monera, tombol materi Protista, tombol materi Jamur (Fungi), serta dilengkapi dengan animasi berupa sebuah movie clip, tombol Sebelumnya, dan tombol Menu Utama yang berfungsi untuk kembali ke Menu Utama. Tampilan menu Materi Biologi dapat dilihat pada gambar berikut ini:

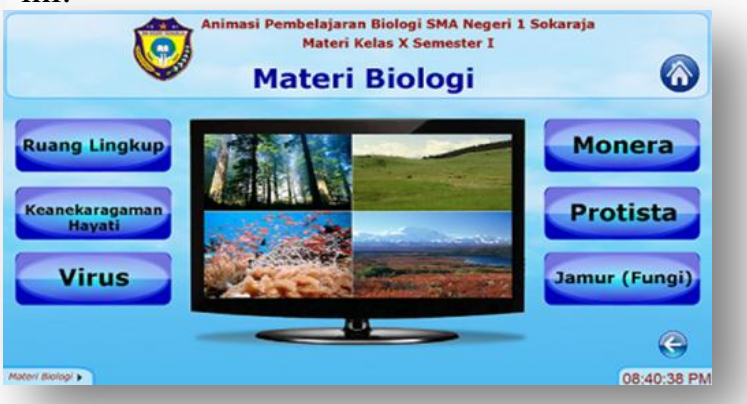

Gambar 6 Tampilan menu Materi Biologi

f. Tampilan halaman menu Virus

Tampilan halaman menu Virus merupakan gerbang untuk melanjutkan ke halaman berikutnya dengan navigasi beberapa tombol materi yang telah disediakan, yaitu: tombol materi Definisi \& Ciri-ciri Virus, tombol materi Morfologi Virus, tombol materi Replikasi Virus, dan tombol materi Peran Virus. Adapun tombol Sebelumnya yang berfungsi untuk kembali ke menu Materi Biologi dan tombol Menu Utama yang berfungsi untuk kembali ke halaman Menu Utama, pada halaman ini 
dilengkapi dengan animasi berupa sebuah movie clip. Tampilan menu Virus dapat dilihat pada gambar berikut ini:

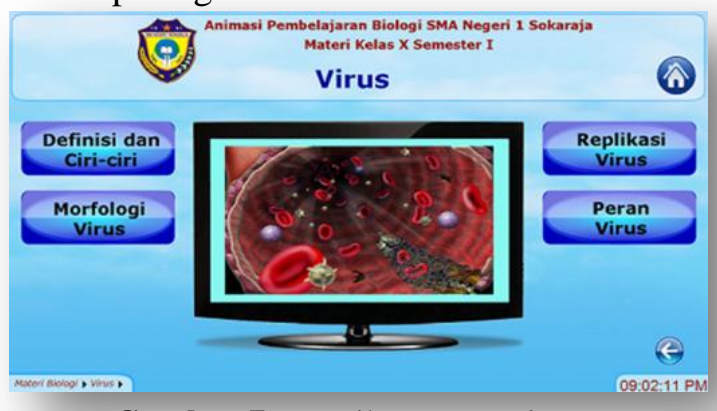

Gambar 7 Tampilan menu Virus

g. Tampilan halaman materi Morfologi Virus

Tampilan halaman ini berisi pembahasan mengenai Morfologi Virus, yang meliputi virus bentuk bulat, virus bentuk batang, virus bentuk huruf $\mathrm{T}$, dan virus bentuk polihedron.Pembahasan materi disertai dengan tampilan gambar-gambar virus dan gambar animasi virus. Adapun dilengkapi dengan tombol Sebelumnya yang berfungsi untuk kembali ke menu Virus, tombol Berikutnya berfungsi untuk menuju ke materi selanjutnya, dan tombol Menu Utama yang berfungsi untuk kembali ke halaman Menu Utama. Tampilan halaman materi Morfologi Virus dapat dilihat pada gambar berikut ini:

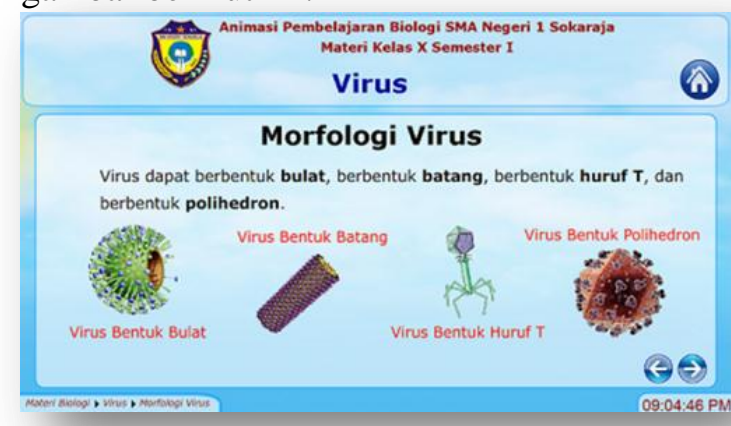

Gambar 8. Tampilan materi Morfologi Virus

$$
\text { yh }
$$

Pengujian Sistem

Pengujian program merupakan tahap akhir dari perancangan sistem yang dibuat. Program dianggap berhasil jika input, proses dan output aplikasi berjalan dengan baik serta sesuai dengan tujuan yang ingin dicapai. Pengujian program dilakukan menggunakan metode Black Box Test, dengan cara mempresentasikan program kepada 1 Guru Biologi dan 35 siswa di SMA Negeri 1 Sokaraja.

Pengujian program aplikasi menggunakan Skala Dikotomi, skala ini memberikan nilai dikotomi misalnya nilai Ya atau Tidak, tipe data yang digunakan adalah nominal. Sedangkan pengambilan sampel dilakukan secara Probabilitas dengan metoda Cluster Sampling, yaitu pengambilan sampel yang dilakukan dengan membagi populasi menjadi beberapa grup bagian.Responden yang melakukan uji coba ini adalah 1 Guru Biologi dan 35 siswa di SMA Negeri 1 Sokaraja dengan pengisian kuesioner mengenai program yang dihasilkan dengan memberi tanda silang.Nama responden yang melakukan pengujian Black box test.

A. Hasil test untuk Guru, Jumlah responden satu orang dengan jumlah pertanyaan kepada responden sebanyak 10. Dari hasil di atas dapat dilihat prosentase untuk jawaban ya sebanyak $70 \%$ dan untuk jawaban tidak sebanyak $30 \%$.

B. Hasil test untuk Siswa, Jumlah responden 35 siswa dengan jumlah pertanyaan kepada responden sebanyak 8. Dengan adanya pengujian sistem pada siswa yang menggambarkan minat belajar dalam memahami materi Biologi dapat diperoleh prosentase $82,86 \%$. Sedangkan untuk prosentase keseluruhan aplikasi pembelajaran Biologi adalah $82,86 \%$ untuk jawaban ya, dan $17,14 \%$ untuk jawaban tidak.

Dari hasil pengujian black box, maka program aplikasi layak untuk diimplementasikan.

\section{Kesimpulan Dan Saran}

Dari hasil pengujian Black box ditarik kesimpulan program aplikasi dinyatakan dapat memudahkan dan meningkatkan minat belajar siswa dengan prosentase $82,86 \%$, sedangkan prosentase keseluruhan program aplikasi adalah $82,86 \%$ untuk jawaban ya, dan 17,14\% untuk jawaban tidak. Maka dari itu program aplikasi animasi pembelajaran Biologi dapat membantu proses belajar mengajar materi Biologi di SMA. 


\section{Daftar Pustaka}

[1] Aryadi, J., "Pembuatan Media Pembelajaran Biologi Untuk Kelas $X$ Dengan Pokok Bahasan Serangga Berbasis Multimedia", STIMIK AMIKOM, Yogyakarta, 2011.

[2] Bunadi, Suriman dan Zeembry, "Membuat Animasi Kartu Ucapan dengan Flash 8", PT Elex Media Komputindo, Jakarta, 2007.

[3] Hofstetter, Fred T., "Multimedia Literacy Third Edition", McGrawHill companies, New York, 2001.

[4] Jogiyanto, "Metodologi Penelitian Sistem Informasi", Andi Offset, Yogyakarta, 2008.

[5] Kistinnah, Idun dan Endang Sri Lestari, "Biologi 1 : Makhluk Hidup dan Lingkungannya Untuk SMA/MA Kelas X", CV Putra nugraha, Jakarta, 2009.

[6] Ladjamudin B, Al Bahra, "Rekayasa Perangkat Lunak", Graha Ilmu, Yogyakarta, 2006.

[7] Madcoms, "Adobe Flash CS3 Untuk Pemula", Andi offset, Yogyakarta, 2008.

[8] Madcoms, "Mahir dalam 7 hari : Adobe Photoshop CS3", Andi offset, Yogyakarta, 2008.

[9] Miarso, Y., "Menyemai Benih Teknologi Pendidikan", Kencana Prenada Media Group, Jakarta, 2004.

[10] Prihatmoko, Emy Taufan., "Analisa Dan Perancangan Pembelajaran Bahasa Inggris Berbasis Multimedia Bagi Anak-anak Pra-Sekolah Dasar", Skripsi S-1, STIMIK Tunas Bangsa, Banjarnegara, 2010. 